\title{
Doğu Karadeniz Şehirlerine Yönelik Marka Şehir Tutumları Üzerine Bir Araştırma
}

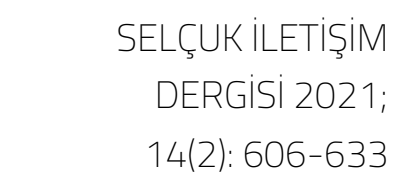

doi: 10.18094/ JOSC.813131

\section{Emre Ş. Aslan, Erdem Taşdemir, Ali Erkam Yarar}

\section{ÖZ}

Şehirler, bir yerleşim yeri olmakla birlikte aynı zamanda sosyal, kültürel ve ekonomik etkileşim merkezleridir. Şehirlerin en önemli görevlerinden biri vatandaşlarının huzurunu ve refahını artırmaktır. Şehirlerin bu görevlerini yerine getirebilmeleri için somut değerlerin yanında soyut değerler de üretmeleri gerekmektedir. Bu soyut değerlerin başında marka yer almaktadır. Şehirlerin markalaşma yolu ile soyut değerlere sahip olması, bir ürünün ulaşamayacağı derecede yüksek gelire ulaşması anlamına gelmektedir. Bu yüksek gelire ulaşmak isteyen şehirlerin son yıllarda markalaşma çalışmalarına önem verdikleri görülmektedir. Markalaşma çalışmaları çoğunlukla dış hedef kitleye yönelik yapılmaktadır. Ancak, iç hedef kitlede markalaşmayan hiçbir ürün, hizmet veya değer, gerçekten markalaşmış olmaz. Markanın en önemli temsilcilerinden olan iç hedef kitle, aynı zamanda markanın bir taşıyıcısı ve inşa edicisi konumundadır.

İç hedef kitleye diğer bir ifadeyle o şehirde ikamet eden bireylere odaklanan bu araştırma, bireylerin kendi şehirleriyle ilgili marka tutumlarını ölçmeyi amaçlamaktadır. Doğu Karadeniz Bölgesi'nde yer alan yedi şehir üzerinde gerçekleştirilen bu araştırmada, her bir şehirde yaşayan şehir sakinlerine kendi şehirleri ile ilgili marka tutumları sorulmuş ve elde edilen cevaplar analiz edilmiştir. İstatistik paket programı yardımıyla analiz edilen sonuçlar, temelde iki farklı boyutta incelenmiştir. İlk boyut tüm şehirlerden toplanan verilerle bölge şehirlerinin geneline yönelik tutumları içerirken, ikinci boyutta ise her bir şehir ayrı ayrı analiz edilmektedir. Frekans, güvenilirlik ve faktör analizlerinden yararlanılan bu araştırma, 1315 kişi üzerinde uygulanmış ve 1221 anket araştırmaya dahil edilmiştir. Bu çalışmada bölge şehirlerine yönelik genel marka tutumlarının beş faktör çerçevesinde kavramsallaştırılabildiği görülmektedir. Bunlar; aidiyet, özdeğer, farkındalık, kalite ve çekiciliktir.

Anahtar Sözcükler: Marka, Şehir, Marka Şehir, Doğu Karadeniz, Tutum

$\begin{array}{lll}\text { EMRE Ş. ASLAN } & \text { ERDEM TAŞDEMIR } & \text { ALI ERKAM YARAR } \\ \text { Doç. Dr. } & \text { Prof. Dr. } & \text { Dr. Öğr. Üyesi } \\ \text { Trabzon Üniversitesi } & \text { Trabzon Üniversitesi } & \text { Necmettin Erbakan Üniversitesi } \\ \text { emresaslan@gmail.com } & \text { etasdemir29@gmail.com } & \text { aeyarar@erbakan.edu.tr } \\ \text { ORCID ID: 0000-0002-5710-3743 } & \text { ORCID ID:0000-0002-9781-4099 } & \text { ORCID ID: 0000-0002-0919-314X }\end{array}$

SELÇUK ILETIŞIM DERGISI 2021; 14(2): 606-633

doi: 10.18094/ JOSC.813131

Geliş Tarihi: 20.10.2020 Kabul Tarihi: 13.01.2021 Yayın Tarihi: 25.04.2021 


\section{A Study on Brand Cities Attitude \\ in The Eastern Black Sea Cities in}

Turkey

\section{JOURNAL OF SELÇUK \\ COMMUNICATION 2021; \\ $14(2): 606-633$}

doi: 10.18094/ JOSC.813131

\title{
Emre Ş. Aslan, Erdem Taşdemir, Ali Erkam Yarar
}

\begin{abstract}
Cities, besides being a settlement, are also centers of social, cultural and economic interaction. One of the most important tasks of cities is to increase the peace and well-being of their citizens. In order for cities to fulfill these tasks, they must produce intangible values as well as tangible values. Brand is at the top of intangible values. The fact that cities have intangible values through branding means that a product reaches higher income than it can reach. It is seen that cities that want to reach high income have attached importance to branding efforts in recent years. Branding studies are mostly aimed at external target audience. However, any product, service or value that is not branded in the internal target audience will not be truly branded. The internal target group, one of the most important representatives of the brand, is also a carrier and builder of the brand.

This study focuses on the internal target audience, in other words, individuals residing in that city, aims to measure individuals' brand attitudes towards their cities. In this study conducted on seven cities in the Eastern Black Sea Region, city residents living in each city were asked about their brand attitudes about their cities and the answers obtained were analyzed. The results analyzed with the help of the statistical package program were basically examined in two different dimensions. While the first dimension includes attitudes towards the cities of the region with the data collected from all cities, in the second dimension, each city is analyzed separately. Using frequency, reliability, and factor analysis, this study was applied on 1315 people and 1221 questionnaires were included in the study. In this study, it is seen that general brand attitudes towards the cities of the region can be conceptualized within the framework of five factors. These; belonging, self-worth, awareness, quality and attractiveness.
\end{abstract}

Keywords: Brand, City, City Brand, East Blacksea, Attitude

$\begin{array}{lll}\text { EMRE S. ASLAN } & \text { ERDEM TAŞDEMIR } & \text { ALI ERKAM YARAR } \\ \text { Assoc. Prof. } & \text { Prof. } & \text { Asst. Prof. } \\ \text { Trabzon University } & \text { Trabzon University } & \text { Necmettin Erbakan University } \\ \text { emresaslan@gmail.com } & \text { etasdemir29@gmail.com } & \text { aeyarar@erbakan.edu.tr } \\ \text { ORCID ID: 0000-0002-5710-3743 } & \text { ORCID ID:0000-0002-9781-4099 } & \text { ORCID ID:0000-0002-0919-314X }\end{array}$

JOURNAL OF SELÇUK COMMUNICATION 2021; 14(2): 606-633

doi: 10.18094/ JOSC.813131

\author{
ALI ERKAM YARAR \\ Necmettin Erbakan University \\ ORCID ID: 0000-0002-0919-314X
}




\section{Gíriş}

Batı toplumlarının yüksek refah düzeyine sahip olması ve hemen her şeyi kapitalist bir değere dönüştürme çabaları, beraberinde şehirlerin de bu sürece dahil edilmesini sağlamıştır. Müşteriye ürünün kaynağını işaret eden, benzer ürün üreten rakiplerden koruyan ve farklılaştıran ayırt edici isim, logo, alamet-i farika veya ambalaj tasarımı gibi semboller (Aaker, 2009, s. 25) bütünü olarak tanımlanan markaya sahip olmak veya marka haline gelebilmek için birçok şehir çeşitli çalışmalar yapmaktadır. Ancak şurası bir gerçektir ki, tüm yerler ve yörelerin aynı anda gelişmesi ve zenginleşmesi mümkün değildir. Kaynakların kıt olduğu bir ortamda kazananların ve kaybedenlerin olması oldukça doğaldır (ilgüner \& Asplund, 2011, s. 12). Ancak doğru stratejik marka yatırımı yapanlar ve böylece marka haline gelenlerin bu mücadeleden başarılı çıkma oranları oldukça yüksektir.

Diğer taraftan Türkiye'nin Doğu Karadeniz Bölgesi'nde yer alan şehirler incelendiğinde son yıllarda önemli bir turizm potansiyeline ulaştıkları bir gerçektir. Özellikle Arap turistler tarafından tercih edilen Doğu Karadeniz bölgesine yönelik bu yoğun talebin süreklilik arz edebilmesi bölgenin ve bölge şehirlerinin marka haline gelmesiyle mümkündür. Ancak dış hedef kitlenin gözünde değer kazanabilmek için öncelikle iç hedef kitle tarafından marka olarak algılanmak gerekmektedir. Bu nedenle çalışma Doğu Karadeniz Bölgesi'nde yer alan 7 şehirde (Artvin, Bayburt, Giresun, Gümüşhane, Ordu, Rize, Trabzon) ikamet eden şehir sakinleri üzerinde gerçekleştirilmiştir. Sakinlerin, kendi şehirleri hakkındaki marka şehir tutumlarını ölçmeyi amaçlayan çalışma, alanındaki ilk çalışmalardan biri olması nedeniyle önem arz etmektedir.

Mayıs 2017 ve Temmuz 2019 tarihleri arasında verileri toplanan bu araştırma, toplamda 1221 katıımcıdan elde edilen verilerin analiz edilmesiyle tamamlanmıştır. İstatistik paket programından yararlanılarak elde edilen verilere göre Doğu Karadeniz Bölgesi'ndeki şehirlerde ikamet edenlerin marka şehir tutumlarını 5 başlık altında toplamak mümkündür. Bunlar; aidiyet, özdeğer, farkındalık, kalite ve çekicilik olarak sıralanabilir.

\section{MARKA ŞEHIR}

Latin dillerinde "city" ve "civitas", Arapçada "medine", Yunancada "polis" gibi kavramlarla ifade edilen şehirler (Keleş, 2005, s. 10) her zaman ekonomik bir işleve sahip olmuştur. Ulaşım araçlarında yaşanan devrimler, şehirlerin ekonomik önemlerini de büyük oranda artırmıştır. Kitle turizminin 
gelişmesinin ön koşulu olarak görülen ulaşım (Urry, 2009, s. 44) ile birlikte, kitlelerin turistik faaliyetlere katılması, şehirler arasındaki rekabeti artırmış ve yöneticiler sadece iç dinamiklere odaklanma yaklaşımı yerine dış paydaşları da dikkate alma anlayışına geçiş yapmışlardır.

Bu süreç, beraberinde marka odaklı anlayışı da getirmiştir. Yüksek getiriler sağlayan (Buckingham, 2011, s. 1) ve farklılık yaratan ekonomik değerler bütünü olarak görülen marka (Moon \& Millison, 2003, s. 31), maddi olmayan varlık olarak değer yaratımının en önemli aracı olarak görülmektedir (Roll, 2011, s. 43). Ürünler, hizmetler veya şehirlerin ana mücadelesini oluşturan değer yaratımı çabalarının markalaşmayla mümkün hale gelmesi, yöneticilerin bu konulara odaklanmasını sağlamaktadır.

Ticaret, sanayi ve hizmet alanlarının yoğunlaştığı gelişmiş yerleşim merkezleri olarak görülen şehirler (Ustakara, 2015, s. 75), sakinlerinin refahını ve mutluluğunu artırabilmek için sürekli olarak değer üretmek zorundadırlar. Bir metafizik varlık olarak sürekli tüketicinin zihninde yaşayan markaların (Forrest, 2001, s. 97) güçlü bir değer üreticisi olmaları, şehir yöneticilerinin de markalaşma çalışmalarına önem vermesini sağlamaktadır. Diğer şehirlere nazaran üstünlük ve avantajı bir konum elde etmek isteyen şehirler, bir yandan hedef kitlesinin zihninde özel bir yer ve olumlu imaj oluşturmaya çalışırken (Işık \& Erdem, 2015, s. 32), şehir sakinlerinin refahını ve mutluluğunu artırmak, şehri bir cazibe merkezi haline getirmek gibi markalaşma faaliyetlerini de yürütebilmelidir. Özellikle yerel siyasetçilerin en fazla kullandıkları kavramlardan olan marka şehir kavramı, idealize edilmiş değerli bir rüyayı simgelemektedir. Bu rüyaya ulaşmak isteyen şehirler için markalaşma uzun ve zahmetli bir süreci gerektirmektedir.

\section{Marka Şehir Oluşum Süreci}

Bir şehrin marka haline gelebilmesi bir anda gerçekleştirilebilecek bir olay değildir ve bir sürece intiyaç duymaktadır. Genel hatlarıyla markalama süreci, müşterilerin marka ile kurdukları etkileşimlerin tümünün olumlu bir algı oluşturacak şekilde planlanmasını kapsamaktadır (Elden, 2009, s. 103). Bir grup insanın ideal bir imaj oluşturma çabasıyla başlayan markalama süreci (Klein, 2002, s. 178-179) nihayetinde hedef kitleyi rakipler yerine kendimizin tercih edilmesine inandırma (Broadbent, 2003, s. 27) faaliyetlerini kapsamaktadır. Bu süreç, uygun ismin verilmesini ve işletmenin veya bir şehrin kendi ürünlerini tanımlamasını (Doyle, 2001, s. 8) ve farklılaşmasını da kapsamaktadır (Klein, 2002, s. 29-30). Dolayısıyla bir şehrin markalaşma süreci, tarihsel süreç içerisindeki durumunu, şehirleşme sürecindeki 
mücadelesini, ürünlerinin tanımlanmasını, farklılaştırılmasını ve o yerin gelecek vizyonunu kapsayan meşakkatli bir periyodu içermektedir.

Bu sürecin sağıklı bir şekilde yürütülebilmesi için dikkat edilmesi ve asla yapılmaması gerekenleri şu şekilde sıralamak mümkündür (Herstein , Berger, \& Jaffe, 2013, s. 396-399):

- Miyopluk (Myopia)

- Hatalı Odaklanma (Misguided)

- Minimize Etme (Minimised)

- Hatalı Konumlandırma (Mispositioned)

- Hatalı Pazarlama (Mismarketed)

Miyopluk, planlama ve fikir üretme süreçlerindeki uzun dönemli yaklaşımların yetersizliği olarak tanımlanırken, hatalı odaklanma ise paydaşlar arasındaki iş birliği eksikliğini ve amaç birlikteliği uyumsuzluğunu anlatmaktadır. Minimize etmek olarak tanımlanan hata ise markalaşma sürecinin kısa dönemli stratejiler ve taktiklerle yürütülmeye çalışılmasıdır. Hâlbuki markalama uzun dönemli bir süreci gerektirmektedir. Hatalı konumlandırma ise şehirlerin yeterince özgünleştirilememesi veya farklılaştırılamaması durumuyla ilgili iken hatalı pazarlama ise daha çok şehrin nasıl sunulacağı üzerine odaklanmaktadır. Şehirler pazarlanırken çoğunlukla hedef kitleden kopuk, yeni iletişim araçlarına yabancı ve faydası hesaplanmamış bir anlayışla hareket edilmektedir.

Şehirlerin markalaşma süreci, altyapıdan üstyapıya, sosyal sorunlardan fiziki şartlara, psikolojik unsurlardan kültürel ve ekonomik faaliyetlere, tarihsel dayanaklardan gelecek beklentilerine kadar birçok faktörden etkilenmektedir (Aslan, 2018, s. 35). Bu nedenle şehir markalama sürecinde psikolojiden sosyolojiye, ekonomiden iletişime kadar birçok disiplinden yararlanmak gerekmektedir (Ustakara, 2015, 5. 90).

Marka Şehir oluşum sürecinin sağlıklı yürütebilmesi ve yukarıda vurgulanan hatalara düşülmemesi için atılması gereken adımları Keller'in (2008, s. 38) stratejik marka yönetimi süreçlerin de katkısıyla şu şekilde yeniden tanımlamak mümkündür:

- Marka Şehir Platformunun Oluşturulması

- Marka Konumlandırma çerçevesinin tanımlanması ve oluşturulması,

- Marka pazarlamasının nasıl yapılacağının planlanması ve uygulanması, 
- Marka Şehir bilincinin İnşa Edilmesi

- Yerel Gurur Öğelerinin Yaratılması

- Başarıya İnanç Algısının İnşası

- Marka Şehir Bilincinin İçselleştirilmesi

- Marka Şehir İletişim Yönetimi Gerçekleştirilmesi

- Marka performansının ölçülmesi, değerlendirilmesi ve yorumlanması

- Marka denkliği ya da ederinin geliştirilmesi ve sürdürülmesi

Aslan (Aslan, 2018) şehirlerin markalaşma süreçlerinin sağlıklı yürütülebilmesi ve ortak bir akıl çerçevesinde kararların alınabilmesi için bir marka şehir platformunun kurulması gerektiği üzerinde durmaktadır. Ayrıca çok sayıda hedef kitle ve paydaş grupları arasında odaklanılması gereken en önemli gruplardan birisi olan şehir sakinlerine (Kavaratzis, 2004, s. 66) gerçek bir marka şehir inşasını gerçekleştirebilmek için ihtiyaç duyulan bilincin benimsetilmesi, yerel gurur öğelerinin neler olacağının belirlenmesi ve bunlara sahip çııılması, başarıya inanç algısının oluşturulması gerekmektedir. Tüm bu çabaların yanında marka şehir bilincinin hem platform üyeleri tarafından hem yöneticiler hem de şehir sakinleri tarafından içselleştirilmesi gerekmektedir. Ayrıca, markalaşmanın temel kuralı olan iletişim faaliyetlerinin tek bir elden ve ortak bir algı oluşturacak şekilde yönetilmesine ihtiyaç duyulmaktadır.

\section{ARAŞTIRMA}

\section{Araştırmanın Amacı ve Önemi}

Son yıllarda özellikle Arap turistlerin talepleriyle birlikte turistik faaliyetlerde gözde bir bölge haline gelen (www.hurriyet.com, 2018; Akkaya \& Sezgin, 2015, s.28). Türkiye'nin Doğu Karadeniz Bölgesi'nde yer alan şehirlere yönelik bu talebin sürdürülebilmesinde markalaşmanın önemli bir rol üstleneceği düşünülmektedir. Ancak markalaşma süreci her şeyden önce iç markalaşmayla başarıya ulaşabilecektir. Bu çerçevede, araştırma ile şehir sakinlerinin nezdinde Doğu Karadeniz Bölgesi'nde bulunan şehirlere yönelik marka tutumlarının ne olduğunun ortaya konması amaçlanan bu çalışmada, benzer çalışmaların aksine dış paydaşlar yerine iç paydaşların tutumlarına odaklanmaktadır. Bu çalışmanın önemi, öncelikle şehir sakinlerinin kendi şehirleriyle ilgili marka tutumlarını ölçen nadir çalışmalardan biri olmasından kaynaklanmaktadır. 


\section{Araştırmanın Hipotezleri}

Bu çalışmanın hipotezleri aşağıdaki gibi kurgulanmıştır.

$\mathrm{H}_{1}$ Doğu Karadeniz şehirlerine yönelik tutumlar cinsiyet değişkeni açısından anlamlı farklıık göstermektedir.

$\mathrm{H}_{2}$ Doğu Karadeniz şehirlerine yönelik tutumlar medeni durum değiş̧keni açısından anlamlı farklılık göstermektedir.

$\mathrm{H}_{3}$ Doğu Karadeniz şehirlerine yönelik tutumlar eğitim durumu değişkeni açısından anlamlı farklılık göstermektedir.

$\mathrm{H}_{4}$ Doğu Karadeniz şehirlerine yönelik tutumlar yaş durum değişkeni açısından anlamlı farklılık göstermektedir.

$\mathrm{H}_{5}$ Doğu Karadeniz şehirlerine yönelik tutumlar gelir durumu değişkeni açısından anlamlı farklıık göstermektedir.

\section{Araştırmanın Evren ve Örneklemi}

Araştırmada Doğu Karadeniz Bölgesi'nde yer alan ve özellikle Doğu Karadeniz Belediyeler Birliğine üye şehirler (www.dkbb.gov.tr, 2021) evren olarak alınmıştır. Bu şehirlerde ikamet eden şehir sakinleriyle sınırlandırılan örneklem Artvin, Bayburt, Giresun, Gümüşhane, Ordu, Rize ve Trabzon olmak üzere toplam 7 şehirden oluşmaktadır. İç markalaşma sürecine yönelik olması nedeniyle bu araştırma, 18 yaşından büyük, okuryazarlığı olan, araştırmanın yapıldığı şehirde ikamet eden kadın ve erkeklerle sınırlandırılmaktadır.

\section{Araştırmanın Kapsam ve Sınırlılıkları}

Araştırmanın kapsam ve sınırlılıkları belirlenirken Doğu Karadeniz Bölgesi'ndeki şehir merkezlerinde gerçekleştirilen bu araştırmada örneklem büyüklükleri, şehirlerin nüfus bakımından büyüklüğüne göre belirlenmiştir. Buna göre, Trabzon ve Ordu'da 270, Rize ve Giresun'da 200, Gümüşhane, Artvin ve Bayburt'ta ise 125 olmak üzere toplamda 1.315 anket şehir sakinleri üzerinde uygulanmıştır. Hatalı olduğu veya ciddiyetle doldurulmadığı gözlemlenen anketlerin kapsam dışı tutulmasıyla 1.221 anket üzerinden analizler gerçekleştirilmiştir. 
Şehirde ikamet etme sınırlılığına sahip olan bu araştırmada, günübirlik veya turizm amaçlı ziyaretçiler, misafir olarak bulunanlar ve ikametgahı farkı bir şehirlerde olanlar araştırmaya dahil edilmeyerek şehrin gerçek sahiplerine odaklanılmaya çalışılmıştır.

\section{Araştırmanın Yöntemi}

Mayıs 2017 ve Temmuz 2019 tarihleri arasında marka şehre yönelik tutumların araştırıldığı bu çalışmada, yöntem olarak nicel araştırmadan yararlanılmıştır. Nicel araştırma yöntemlerinden anket (survey) ile verilerin toplandığı bu çalışmada, elde edilen veriler, bir istatistik paket programı aracılığıyla frekans, kurtosis, skewness, faktör, ki kare gerçekleştirilmiş̧ir. Araştırmanın ölçeği oluşturulurken iki farklı ölçekten ve literatürden yararlanılarak bu çalışmaya özgün olarak geliştirilmiştir. Vazquez ve arkadaşlarının $(2002$, s. 35) marka isminin faydalarını ortaya koymayı amaçlayan ve iki marka isminin sembolik ve fonksiyonel faydasına odaklandıkları ölçek ile, Franzen'in $(2002$, s. 77) kitabında yer alan Schlinger'in reklamlara yönelik izleyici tepkisi profili ölçeğinden (1979) esinlenilerek oluşturulmuştur. Bu yönüyle yeni olma özelliği taşıyan bu ölçek, ön teste tabi tutulmuştur.

\section{Ön Test}

Bu araştırmada kullanılan ölçeğin bu haliyle daha önce kullanılmamış bir ölçek olması nedeniyle ön teste ihtiyaç duyulmuştur. Bu çerçevede 3 araştırmacı dışında alanında uzman 5 kişiye anket soruları okutularak görüşleri alınmış ve gerekli revizeler yapılmıştır. Ardından Trabzon'da 100 katıımcı üzerinde gerçekleştirilen araştırma sonucunda 6 anket kapsam dışı tutulmuş ve 94 anket ön teste tabi tutulmuştur. Elde edilen sonuçlara göre ölçeğin uygulanması için güvenilir olduğu (Cronbach's Alpha ,959) ve örneklem yeterlilik testinin geçerli (KMO ,806) olduğu sonucuna ulaşılmış ve bu çalışmanın uygulanabilir olduğu kanaatine varılmıştır.

\section{Verilerin Analizi ve Bulgular}

Doğu Karadeniz şehirlerinde ikamet edenlerin şehirleriyle ilgili tutumlarını incelemeden önce araştırmaya katılan deneklerin demografik özelliklerine bakıldığında, yaş ve eğitim durumu açısından katılımcıların \%36'sının 18-27 yaş aralığında, \%32,6'sının ise 28-37 yaş aralığında; eğitim durumu açısından ise lise $(\% 30,4)$, önlisans $(\% 26,2)$ ve lisans $(\% 24,1)$ düzeyinde oldukları görülmektedir. Araştırmaya katılanların \%55'inin erkeklerden, \%44,1'inin kadınlardan; \%50,5'inin evliler, \%48,4'ünün ise 
bekârlardan oluştuğu ortaya çıkmaktadır. Katılımcılar, gelir durumları açısından büyük oranda $2.501 \mathrm{TL}$ ile $5.000 \mathrm{TL}$ arasında $(\% 37,4)$ ve $2.500 \mathrm{TL}$ ve altında $(\% 30,4)$ gelire sahip olan bireylerden oluşmaktadır. Mesleki açıdan incelendiğinde en fazla katılım sağlayanların öğrenciler $(\% 14,7)$, memur $(\% 11,5)$, ev hanımı $(\% 10,1)$ olarak sıralandığı ve şehir bazında ise, $\% 22,4$ 'ünün Trabzon'da, $\% 19,7$ 'sinin Ordu'da, \%14,5'inin Rize'de, \%13,8'inin Giresun'da, \%10,6'sının Gümüşhane'de, \%10,2'sinin Artvin'de ve \%9'unun ise Bayburt'ta ikamet edenlerden oluştuğu görülmektedir. Şehirlerden örneklem alınırken şehirlerin nüfus yapıları göz önüne alınarak araştırma planlanmıştır.

\section{Doğu Karadeniz Şehirlerine Yönelik Genel Tutumların Keşfedici Faktör Analizi}

Doğu Karadeniz şehirlerine yönelik tutumları ölçen 40 önermeden oluşan ölçekte yer alan dört önerme, normal dağıım için referans kabul edilen $-3,+3$ şartını taşımaması (skewness $=6,649$ ve Kurtosis $=141,347$ ) nedeniyle kapsam dışı tutulmuştur. Ayrıca üç önermenin de herhangi bir faktör içerisinde yer almaması nedeniyle ortalama değerlerine Tablo1'de yer verilmektedir.

Tablo 1 Doğu Karadeniz Şehirlerine Yönelik Genel Tutumların Keşfedici Faktör Analizine Dahil Edilmeyen Önermelerin Tanımlayııı İstatistikleri

\begin{tabular}{lllll}
\hline & ORT. & S.S & SKEW. & KURT. \\
\hline $\begin{array}{l}\text { FADEÖ1-Bu şehrin sahip olduğu sembolün hatırlanma } \\
\text { düzeyi yüksektir. }\end{array}$ & 3,55 & 1,445 & 6,649 & 141,347 \\
$\begin{array}{l}\text { FADEÖ2-Bu şehrin sahip olduğu tarımsal ve hayvansal } \\
\text { ürünler yüksek kalitedir. }\end{array}$ & 3,60 & 1,133 &,- 644 &,- 307 \\
$\begin{array}{l}\text { FADEÖ3-Imkânım olsa bu şehirden hemen taşınırım. } \\
\text { FADEÖ4-Bu şehir güvenilir bir şehirdir. }\end{array}$ & 2,56 & 1,372 &, 409 & $-1,085$ \\
& 4,05 & 1,022 & $-1,118$ &, 840 \\
\hline
\end{tabular}

Yukarıdaki tablodan hareketle, Doğu Karadeniz Bölgesi'nde yer alan şehirlerin güvenilir şehirler olduğu $(4,05)$, bu şehirlerin sahip oldukları tarımsal ve hayvansal ürünlerin yüksek kalitede olduğu $(3,60)$, bu şehirlerin sahip olduğu sembollerinin hatırlanma düzeyinin yüksek olduğu $(3,55)$ söylenebilir. Katılımcılar, imkânları el verdiğinde dahi bu şehirden taşınmayı düşünmediklerini $(2,56)$ ifade etmektedirler.

Araştırmaya dahil edilmeyen yukarıdaki önermelerin dışında geri kalan 36 önermeyle faktör analizi gerçekleştirilmiştir. Güvenilirlik (Cronbach's Alpha ,967) ve geçerlilik (KMO Measure of Sampling Adequacy, 969) derecesi mükemmel derecede iyi olan bu ölçeği oluşturan önermelerin toplamda 5 
faktörde (aidiyet, özdeğer, farkındalık, kalite ve çekicilik) tanımlanabildiği görülmektedir (bkz. Tablo 2 ve Tablo 3.).

Tablo 2 Doğu Karadeniz Şehirlerine Yönelik Genel Tutumların Keşfedici Faktör Analizi

\begin{tabular}{|c|c|c|c|c|c|}
\hline & ORT. & S.S & SKEW. & KURT. & FAC \\
\hline \multicolumn{6}{|l|}{ FAKTÖR 1: AIDIYET FAKTÖRÜ } \\
\hline A1-Bu şehrin aileme değer kattığına inanıyorum. & 3,52 & 1,127 &,- 620 &,- 303 & ,739 \\
\hline $\begin{array}{l}\text { A2-Bu şehrin bir ferdi olmak şehir içerisinde } \\
\text { özgüvenimi artırmaktadır. }\end{array}$ & 3,49 & 1,170 &,- 559 &,- 476 & ,736 \\
\hline A3-Bu şehirde kendimi değerli hissediyorum. & 3,45 & 1,236 &,- 533 &,- 705 &, 722 \\
\hline A4-Bu şehir sanki benim ayrılmaz bir parçam. & 3,51 & 1,223 &,- 547 &,- 636 & ,720 \\
\hline $\begin{array}{l}\text { A5-Başka bir şehre gittiğim zaman bir an önce } \\
\text { buraya dönme arzusuna kapılıyorum. }\end{array}$ & 3,48 & 1,257 &,- 505 &,- 716 & 700 \\
\hline A6-Bu şehrin bana değer kattığına inanıyorum. & 3,42 & 1,144 &,- 492 &,- 508 & ,693 \\
\hline A7-Kendimi bu şehirde özgür hissediyorum. & 3,64 & 1,266 &,- 688 &,- 560 & 691 \\
\hline A8-Bu şehirde yaşamak bana mutluluk veriyor. & 3,72 & 1,163 &,- 783 &,- 114 & ,691 \\
\hline A9-Bu şehrin ismini ne zaman duysam mutlu olurum. & 3,85 & 1,134 &,- 976 & 293 & 6,77 \\
\hline A10-Bu şehir bende güzel hatıralar barındırıyor. & 3,87 & 1,094 &,- 952 & ,307 & ,664 \\
\hline A11-Bu şehir yaşam tarzıma uygun bir şehirdir. & 3,53 & 1,256 &,- 613 &,- 619 & ,633 \\
\hline $\begin{array}{l}\text { A12-Bu şehrin bir ferdi olmak il dışındayken } \\
\text { özgüvenimi artırmaktadır. }\end{array}$ & 3,50 & 1,213 &,- 563 &,- 578 & 620 \\
\hline A13-Bu şehir bana çekici/cazibeli gelmektedir. & 3,37 & 1,224 &,- 417 &,- 795 & ,600 \\
\hline $\begin{array}{l}\text { A14-Bu şehir sosyal çevreme yaşamak için ideal bir } \\
\text { yer olduğunu tavsiye edebileceğim bir şehirdir. }\end{array}$ & 3,52 & 1,150 &,- 510 &,- 535 &, 573 \\
\hline $\begin{array}{l}\text { A15-Gelecekte ne kadar olumsuzlukla karşılaşırsam } \\
\text { karşılaşayım, bu şehri sevmeye ve desteklemeye } \\
\text { devam edeceğim. }\end{array}$ & 3,82 & 1,135 &,- 876 & ,087 &, 556 \\
\hline $\begin{array}{l}\text { A16-Bu şehir sosyal çevreme ziyaret etmeleri için } \\
\text { tavsiye edebileceğim bir şehirdir. }\end{array}$ & 3,68 & 1,147 &,- 796 &,- 081 &, 525 \\
\hline $\begin{array}{l}\text { A17-Bu şehir mimari yapısı, kokusu, iklimi, doğası vb. } \\
\text { her şeyiyle hoşuma gidiyor. }\end{array}$ & 3,73 & 1,152 &,- 749 &,- 232 &, 520 \\
\hline \multicolumn{6}{|l|}{ FAKTÖR 2: ÖZDEĞER FAKTÖRÜ } \\
\hline Ö1-Bu şehir Türkiye'de önde gelen bir şehirdir. & 2,82 & 1,276 & 160 &,- 996 & ,762 \\
\hline $\begin{array}{l}\text { Ö2-Bu şehir Doğu Karadeniz Bölgesi'nde önde gelen } \\
\text { lider bir şehirdir. }\end{array}$ & 3,26 & 1,321 &,- 291 & $-1,051$ & ,749 \\
\hline $\begin{array}{l}\text { Ö3-Bu şehir tanınmış kişiler tarafından beğenilen- } \\
\text { tavsiye edilen bir şehirdir }\end{array}$ & 3,10 & 1,200 &,- 103 &,- 835 & ,680 \\
\hline Ö4-Bu şehirde yaşamak bir prestij göstergesidir. & 3,03 & 1,217 &,- 078 &,- 856 & ,669 \\
\hline Ö5-Bu şehir Türkiye ölçeğinde marka bir şehirdir. & 3,05 & 1,253 &,- 072 &,- 978 & ,628 \\
\hline $\begin{array}{l}\text { Ö6-Bu şehir Türkiye'deki diğer şehirlere göre daha } \\
\text { yüksek bir tanınırlık düzeyine sahiptir. }\end{array}$ & 2,97 & 1,281 &,- 021 & $-1,138$ & ,616 \\
\hline $\begin{array}{l}\text { Ö7-Bu şehir üstün kalite niteliklerine sahip bir } \\
\text { şehirdir. }\end{array}$ & 3,00 & 1,142 &,- 005 &,- 720 &, 574 \\
\hline $\begin{array}{l}\text { Ö8-Bu şehir Türkiye'deki diğer şehirlere göre daha ilgi } \\
\text { çekici bir şehirdir. }\end{array}$ & 3,15 & 1,210 &,- 190 &,- 929 &, 524 \\
\hline
\end{tabular}




\begin{tabular}{|c|c|c|c|c|c|}
\hline $\begin{array}{l}\text { Ö9-Bu şehir yaşam standartlarına göre iyi değer } \\
\text { sunan bir şehirdir. }\end{array}$ & 3,26 & 1,131 &,- 306 &,- 593 &, 454 \\
\hline $\begin{array}{l}\text { Ö10-Ben bir turist olsam istikrarlı bir şekilde bu şehri } \\
\text { tercih ederim. }\end{array}$ & 2,96 & 1,251 &,- 029 &,- 992 &, 428 \\
\hline \multicolumn{6}{|l|}{ FAKTÖR 3: FARKINDALIK FAKTÖRÜ } \\
\hline F1-Bu şehrin logosunu nerede görsem tanırım. & 3,71 & 1,204 &,- 731 &,- 400 & ,750 \\
\hline F2-Bu şehir özgün bir logoya sahiptir. & 3,40 & 1,241 &,- 376 &,- 902 & ,686 \\
\hline F3-Bu şehir özgün bir sembole sahiptir. & 3,61 & 1,213 &,- 677 &,- 487 & ,658 \\
\hline F4-Bu şehri hayal etmekte zorlanmam. & 3,87 & 1,069 &,- 920 & ,299 & 639 \\
\hline F5-Bu şehir özgün bir slogana sahiptir. & 3,35 & 1,239 &,- 334 &,- 851 & ,633 \\
\hline $\begin{array}{l}\text { F6-Bu şehrin sahip olduğu özellikler hemen aklıma } \\
\text { gelir. }\end{array}$ & 3,89 & 1,073 &,- 988 & ,369 & ,614 \\
\hline $\begin{array}{l}\text { F7-Bu şehir, sahip olduğu değerler, göstergeler vb. } \\
\text { dolayı yüksek bir hatırlanma düzeyine sahiptir. }\end{array}$ & 3,54 & 1,172 &,- 507 &,- 565 &, 589 \\
\hline $\begin{array}{l}\text { F8-Bu şehir Türkiye'deki diğer şehirlere göre özgün } \\
\text { bir tarza sahiptir. }\end{array}$ & 3,51 & 1,213 &,- 655 & ,070 &, 474 \\
\hline F9-Birçok şey bana bu şehri çağrıştırmaktadır. & 3,40 & 1,200 &,- 448 &,- 718 &, 442 \\
\hline \multicolumn{6}{|l|}{ FAKTÖR 4: KALITE FAKTÖRÜ } \\
\hline $\begin{array}{l}\text { K1-Bu şehrin sahip olduğu sanayi ürünleri yüksek } \\
\text { kalitededir. }\end{array}$ & 2,48 & 1,166 & ,393 &,- 727 & ,756 \\
\hline $\begin{array}{l}\text { K2-Bu şehrin sahip olduğu hizmet kalitesi üst } \\
\text { seviyededir. }\end{array}$ & 2,71 & 1,200 & ,205 &,- 896 & ,711 \\
\hline $\begin{array}{l}\text { K3-Bu şehrin sahip olduğu turistik ürünleri yüksek } \\
\text { kalitededir. }\end{array}$ & 3,02 & 1,214 &,- 165 &,- 944 &, 572 \\
\hline $\begin{array}{l}\text { K4-Bu şehir sürekli olarak özelliklerini } \\
\text { geliştiren/iyileştiren bir şehirdir. }\end{array}$ & 3,11 & 1,182 &,- 215 &,- 774 &, 440 \\
\hline \multicolumn{6}{|l|}{ FAKTÖR 5: ÇEKICILIK FAKTÖRÜ } \\
\hline Ç1-Bu şehir eşsiz tarihi güzelliklere sahiptir. & 3,80 & 1,090 &,- 772 &,- 040 & ,744 \\
\hline Ç2-Bu şehrin sahip olduğu kültürel özellikler eşsizdir. & 3,71 & 1,073 &,- 634 &,- 176 & ,692 \\
\hline Ç3-Bu şehir eşsiz doğal güzelliklere sahiptir. & 4,17 & 1,004 & $-1,310$ & 1,304 &, 590 \\
\hline Ç4-Ben bir turist olsam ilk tercihim bu şehir olur. & 2,95 & 1,285 & 015 & $-1,045$ & ,464 \\
\hline
\end{tabular}

17 önermeden oluşan aidiyet faktörünün güvenilirlik derecesi (Cronbach's Alpha) ,952'dir (bkz. Tablo 3). Aidiyet faktörünü oluşturan önermeler incelendiğinde tüm önermelere yüksek katılım gösterildiği görülmektedir. Daha açık bir ifadeyle katılımcılar ikamet ettikleri şehirlerinin kendilerinde güzel hatıralar barındırdığını $(3,87)$, o şehrin ismini ne zaman duysalar mutlu olduklarını $(3,85)$, gelecekte ne kadar olumsuzlukla karşılaşırlarsa karşılaşsınlar o şehri sevmeye ve desteklemeye devam edeceklerini $(3,82)$ dile getirmektedirler. Katılımcılar, o şehrin mimari yapısı, kokusu, iklimi, doğası vb. her şeyiyle hoşlarına gittiğini $(3,73)$ ve o şehirde yaşamanın kendilerine mutluluk verdiğini de $(3,72)$ düşünmektedirler. Yine ikamet ettikleri şehirlerini sosyal çevrelerine ziyaret etmeleri için tavsiye edeceklerini $(3,68)$, o şehirde kendilerini özgür hissettiklerini $(3,64)$, yaşam tarzlarına uygun olduğunu 
$(3,53)$, sosyal çevrelerine yaşamak için ideal bir yer olduğu tavsiyesinde bulunabileceklerini $(3,52)$ ifade etmektedirler. Ayrıca katılımcıların şehirlerini, ailelerine değer katan (3,52), kendilerinin ayrılmaz bir parçası olan $(3,51)$, il dışındayken $(3,50)$ ve il içindeyken özgüvenlerini artıran $(3,49)$ bir yer olarak gördükleri anlaşılmaktadır. İkamet ettikleri şehirden başka bir şehre gittikleri zaman bir an önce geri dönme arzusuna kapıldıklarını $(3,48)$, o şehirde kendilerini değerli hissettiklerini $(3,45)$ dile getiren katıımcıların, o şehrin kendilerine değer kattığı $(3,42)$ ve o şehrin kendilerine çekici/cazibeli geldiği $(3,37)$ yönünde bir tutuma sahip oldukları görülmektedir.

İkinci faktör ise özdeğer faktörü olarak isimlendirilmiştir. 10 önermeden oluşan özdeğer faktörünün oldukça güvenilir olduğu (Cronbach's Alpha, 914) görülmektedir (bkz. Tablo 3). Bu faktörü oluşturan önermelerden 7 tanesine katılım gösterildiği fakat 3 tanesine katılım gösterilmediği görülmektedir. Özdeğer faktörünü oluşturan önermeler incelendiğinde katılımcıların ikamet ettikleri şehirlerini Doğu Karadeniz Bölgesi'nde önde gelen $(3,26)$, kendi yaşam standartlarına göre iyi değer sunan $(3,26)$ ve Türkiye'deki diğer şehirlere göre daha ilgi çekici $(3,15)$ bir şehir olarak gördükleri anlaşıımaktadır. Ayrıca bu kişilerin, şehirlerinin tanınmış kişiler tarafından beğenilen-tavsiye edilen bir şehir olduğu $(3,10)$ yönünde kanaate sahip oldukları anlaşılmaktadır. Katılımcıların kendi şehirlerini Türkiye ölçeğinde marka bir şehir $(3,05)$, yaşamak için prestij göstergesi bir şehir $(3,03)$ olarak gördükleri de ortaya çıkmaktadır. Doğu Karadeniz şehirlerinin üstün kalite niteliklerine sahip olduğu konusuyla ilgili katıımcılar arasında bir kararsızığın olduğu $(3,00)$ anlaşılmaktadır. Diğer taraftan katıımcıların kendi şehirlerinin Türkiye'de önde gelen bir şehir olduğu $(2,82)$, turist olsalar istikrarlı bir şekilde kendi şehirlerini tercih edecekleri görüşüne $(2,96)$ ve ikamet ettikleri şehirlerinin Türkiye'deki diğer şehirlere göre daha yüksek bir tanınırlık düzeyine sahip olduğu inancına $(2,97)$ katılmadıkları ortaya çıkmaktadır.

Doğu Karadeniz şehirlerine yönelik genel tutumların keşfedici faktör analizi sonucunda elde edilen üçüncü faktörü ise farkındalık faktörü olarak isimlendirilmiştir. Oldukça güvenilir olan farkındalık faktörünü (Cronbach's Alpha ,879) oluşturan önermelerin ortalamaları dikkate alındığında katılımcıların tüm ifadelere katıım gösterdikleri anlaşılmaktadır. Katıımcılara göre ikamet ettiklerin şehrin sahip oldukları özellikler hemen akla gelmekte $(3,89)$, şehri hayal ederken zorlanmamakta $(3,87)$ ve şehrin logosu nerede görülse hemen tanınmaktadır $(3,71)$. Şehrin özgün bir sembole sahip olduğu görüşüne $(3,61)$ katılan deneklere göre kendi şehirleri sahip olduğu birçok değer, gösterge vb. dolayı yüksek bir hatırlanma düzeyine sahiptir $(3,54)$. İkamet ettikleri şehirlerinin Türkiye'deki diğer şehirlere göre özgün 
bir tarza sahip olduğunu düşünen $(3,51)$ katılımcılar, şehirlerinin özgün bir logoya $(3,40)$ ve özgün bir slogana da $(3,35)$ sahip olduğu ve birçok şeyin kendilerine şehirlerini çağrıştırdığı $(3,40)$ yönünde bir tutuma sahiptirler.

Bu analizden elde edilen bir diğer faktör ise kalite faktörü olarak isimlendirilmiştir. Cronbach's Alpha değeri ,787 olan kalite faktörünü oluşturan önermelerin ortalamaları incelendiğinde deneklerin iki önermeye katılım gösterdikleri görülmektedir. Buna göre, ikamet edilen şehirler sürekli olarak özelliklerini geliştirmekte/iyileştirmektedir $(3,11)$ ve bu şehirlerin sahip olduğu turistik ürünler yüksek kalitededir $(3,02)$. Buna karşın denekler iki önermeye ise olumlu yönde katılım göstermemişlerdir. Deneklere göre, ikamet ettikleri şehirler sahip oldukları sanayi ürünleri açısından üst kalitede $(2,48)$ ve sundukları hizmet kalitesi açısından üst seviyede $(2,71)$ değildir.

Elde edilen beşinci faktör ise, çekicilik olarak isimlendirilmiştir. Güvenilirlik derecesi iyi seviyededir (Cronbach's Alpha ,763). Toplam dört önermeden oluşan çekicilik faktörünü oluşturan önermeler incelendiğinde, tüm önermeler içerisinde, en yüksek ortalamaya sahip olan ifadenin ikamet edilen şehrin eşsiz doğal güzelliklere sahip olduğuna $(4,17)$ vurgu yapan önerme olduğu görülmektedir. Bunun yanında katılımcılar ikamet ettikleri şehirlerinin eşsiz tarihi güzelliklere $(3,80)$ ve kültürel özelliklere $(3,71)$ sahip olduğu önermelerine de katılım göstermektedirler. Buna karşın denekler bir turist olmaları halinde ilk tercih edecekleri yerin kendi şehirleri olmayacağını $(2,95)$ ifade etmektedirler.

Tablo 3 Doğu Karadeniz Şehirlerine Yönelik Genel Tutumların Keşfedici Faktör Analizinin Güvenilirlik Değerleri

\begin{tabular}{llllll}
\hline & FAC1 & FAC2 & FAC3 & FAC4 & FAC5 \\
\hline Özdeğer (Eigenvalue) & 18,526 & 2,609 & 2,258 & 1,447 & 1,296 \\
Açılanan Varyans & 42,105 & 5,930 & 5,132 & 3,289 & 2,945 \\
Cronbach's Alpha &, 952 &, 914 &, 879 &, 787 &, 763 \\
KMO Measure of Sampling Adequacy & & &, 969 & \\
Bartlett's Test of Sphericity & $X^{2}=29791,931$ & S.D $=, 946$ & P=,000 \\
Cronbach's Alpha & & &, 967 & & \\
\hline
\end{tabular}

\section{Artvin, Bayburt ve Gümüşhane'ye Yönelik Tutumlar}

Nüfus oranları bakımından birbirlerine benzer özellikler taşımaları nedeniyle birlikte analiz edilen Artvin, Bayburt ve Gümüşhane'ye yönelik gerçekleştirilen araştırmayla katılımcıların kendi şehirlerine 
yönelik tutumları ölçülmeye çalışılmaktadır. Elde edilen verilere değinmeden önce araştırmanın güvenilirlik değerlerine yer vermekte yarar vardır.

Artvin'de uygulanan ölçeğin güvenilirlik analizleri gerçekleştirilmiş ve elde edilen sonuçlara göre çalışmanın örneklem yeterlilik testinin iyi derecede geçerli $(K M O=, 802)$ ve mükemmel derecede güvenilir (Cronbach's Alpha ,961) olduğu ortaya çıkmaktadır. Bartlett's testine göre ise her bir önerme ile ana kütle arasında anlamlı bir farklılık olduğu da $\left(X^{2}=3847,783, S . D=, 1128, p=, 000\right)$ gözlemlenmektedir.

Bayburt'ta uygulanan ölçeğin güvenilirlik analizleri gerçekleştirilmiş ve elde edilen sonuçlara göre çalışmanın örneklem yeterlilik testinin iyi derecede geçerli $(K M O=, 844)$ ve mükemmel derecede güvenilir (Cronbach's Alpha ,969) olduğu ortaya çıkmaktadır. Bartlett's testine göre ise her bir önerme ile ana kütle arasında anlamlı bir farklılık olduğu da $\left(X^{2}=3224,777 \mathrm{~S} . \mathrm{D}=, 1128, \mathrm{p}=, 000\right)$ gözlemlenmektedir.

Gümüşhane'yi konu alan ölçeğin örneklem yeterlilik testinin iyi derecede geçerli olduğu (KMO= ,884) ortaya çıkmaktadır. Güvenilirlik analizine göre ise mükemmel derecede güvenilir (Cronbach's Alpha ,960) olan ve Bartlett's testine göre, her bir önerme ile ana kütle arasında anlamlı bir farklılık olduğu da $\left(X^{2}=4412,492, S . D=, 1128, p=, 000\right)$ ortaya çıkan bu ölçekte yer alan önermelerin tanımlayıcı istatistiklerine aşağıda yer verilmektedir.

Gerçekleştirilen tanımlayııı istatistik sonucunda elde edilen verileri iki boyutta ele almak mümkündür. Birincisi katılımcıların olumlu tutum ortaya koydukları veriler, ikincisi ise olumsuz tutuma sahip oldukları veriler.

Tablo 4. Artvin, Bayburt ve Gümüşhane'ye Yönelik Tutumların Ortalamaları

\begin{tabular}{llll|lll|lll}
\hline & \multicolumn{4}{c}{ Artvin } & \multicolumn{3}{c}{ Bayburt } & \multicolumn{3}{c}{ Gümüşhane } \\
\hline & $N$ & ORT. & S.S & N & ORT. & S.S & N & ORT. & S.S \\
F8 & 124 & 3,78 & 1,064 & 109 & 2,72 & 1,421 & 129 & 2,68 & 1,293 \\
Ö6 & 123 & 2,63 & 1,230 & 108 & 2,21 & 1,326 & 129 & 2,00 & 1,061 \\
Ö8 & 122 & 3,16 & 1,078 & 108 & 2,08 & 1,193 & 128 & 2,17 & 1,066 \\
F6 & 124 & 3,88 &, 861 & 109 & 3,22 & 1,430 & 128 & 3,34 & 1,187 \\
F3 & 121 & 3,29 & 1,313 & 104 & 2,86 & 1,410 & 129 & 2,86 & 1,217 \\
FADEÖ1 & 123 & 3,36 & 1,167 & 110 & 2,61 & 1,314 & 129 & 2,82 & 1,135 \\
F2 & 123 & 3,21 & 1,203 & 106 & 2,52 & 1,274 & 129 & 2,64 & 1,223 \\
F1 & 122 & 3,48 & 1,201 & 107 & 3,07 & 1,465 & 129 & 3,18 & 1,215 \\
F3 & 121 & 3,12 & 1,185 & 105 & 2,70 & 1,322 & 129 & 2,66 & 1,189 \\
F4 & 122 & 3,84 &, 909 & 104 & 3,51 & 1,358 & 129 & 3,39 & 1,181 \\
F7 & 123 & 3,22 & 1,251 & 108 & 3,03 & 1,329 & 129 & 2,81 & 1,158 \\
F9 & 120 & 3,42 & 1,157 & 108 & 2,62 & 1,372 & 129 & 2,72 & 1,225
\end{tabular}




\begin{tabular}{|c|c|c|c|c|c|c|c|c|c|}
\hline K2 & 123 & 2,63 & 1,216 & 105 & 1,96 & 1,134 & 129 & 2,15 & 1,076 \\
\hline K1 & 120 & 2,09 & 1,138 & 110 & 1,83 & 1,048 & 129 & 1,98 & ,984 \\
\hline K3 & 122 & 2,93 & 1,316 & 105 & 2,01 & 1,139 & 129 & 2,40 & 1,107 \\
\hline FADEÖ2 & 122 & 3,74 & 1,156 & 107 & 3,31 & 1,306 & 129 & 3,19 & 1,151 \\
\hline Ç3 & 123 & 4,26 & 957 & 108 & 3,18 & 1,338 & 129 & 3,84 & 1,052 \\
\hline Ç1 & 123 & 3,86 & 1,066 & 108 & 3,38 & 1,243 & 129 & 3,67 & 1,069 \\
\hline Ç2 & 123 & 3,74 & 965 & 105 & 3,32 & 1,297 & 129 & 3,39 & 1,134 \\
\hline Ç4 & 123 & 3,22 & 1,170 & 108 & 1,82 & 1,057 & 129 & 2,08 & 1,050 \\
\hline Ö10 & 122 & 3,14 & 1,108 & 107 & 2,06 & 1,235 & 129 & 2,25 & 1,153 \\
\hline A15 & 124 & 3,88 & 1,056 & 108 & 3,47 & 1,501 & 129 & 3,75 & 1,234 \\
\hline Ö5 & 123 & 3,09 & 1,228 & 108 & 2,10 & 1,222 & 129 & 2,37 & 1,139 \\
\hline A8 & 123 & 3,81 & 1,190 & 109 & 2,99 & 1,469 & 129 & 3,29 & 1,265 \\
\hline A7 & 123 & 3,84 & 1,097 & 108 & 2,92 & 1,554 & 129 & 3,37 & 1,347 \\
\hline A5 & 124 & 3,40 & 1,355 & 109 & 2,83 & 1,545 & 129 & 3,14 & 1,356 \\
\hline A3 & 123 & 3,54 & 1,216 & 109 & 2,90 & 1,453 & 129 & 3,29 & 1,271 \\
\hline FADEÖ3 & 123 & 2,81 & 1,339 & 108 & 3,23 & 1,568 & 129 & 3,02 & 1,358 \\
\hline A6 & 124 & 3,49 & 1,151 & 109 & 2,81 & 1,384 & 129 & 3,13 & 1,188 \\
\hline A1 & 124 & 3,73 & 1,037 & 108 & 3,02 & 1,434 & 129 & 3,17 & 1,213 \\
\hline A2 & 124 & 3,60 & 1,096 & 108 & 2,95 & 1,430 & 129 & 3,15 & 1,275 \\
\hline A12 & 124 & 3,39 & 1,228 & 106 & 2,91 & 1,451 & 129 & 2,97 & 1,274 \\
\hline A10 & 124 & 3,85 & 1,187 & 108 & 3,43 & 1,442 & 129 & 3,79 & 1,150 \\
\hline A4 & 124 & 3,68 & 1,101 & 108 & 2,79 & 1,466 & 129 & 3,18 & 1,240 \\
\hline A17 & 124 & 3,93 & 1,083 & 108 & 2,96 & 1,433 & 129 & 3,09 & 1,166 \\
\hline A9 & 124 & 3,94 & 1,065 & 110 & 3,24 & 1,514 & 129 & 3,71 & 1,100 \\
\hline A16 & 124 & 3,87 & 987 & 110 & 2,57 & 1,443 & 129 & 2,98 & 1,114 \\
\hline A14 & 124 & 3,53 & 1,151 & 110 & 2,70 & 1,392 & 129 & 3,02 & 1,139 \\
\hline K4 & 124 & 3,05 & 1,175 & 109 & 2,25 & 1,292 & 129 & 2,73 & 1,051 \\
\hline FADEÖ4 & 123 & 4,20 & 989 & 109 & 4,06 & 1,346 & 129 & 4,16 & 996 \\
\hline Ö9 & 123 & 3,20 & 1,076 & 110 & 2,61 & 1,402 & 129 & 2,60 & 1,086 \\
\hline Ö7 & 124 & 2,96 & 1,171 & 107 & 2,26 & 1,269 & 129 & 2,41 & 973 \\
\hline Ö1 & 123 & 2,80 & 1,145 & 109 & 1,98 & 1,276 & 129 & 2,02 & 1,034 \\
\hline Ö2 & 122 & 3,02 & 1,167 & 110 & 2,15 & 1,270 & 128 & 2,20 & 1,035 \\
\hline Ö4 & 123 & 2,90 & 1,119 & 109 & 2,18 & 1,226 & 129 & 2,26 & 1,099 \\
\hline 0̈3 & 124 & 3,15 & 1,176 & 110 & 2,29 & 1,280 & 129 & 2,28 & 1,031 \\
\hline A13 & 124 & 3,42 & 1,250 & 108 & 2,39 & 1,267 & 129 & 2,61 & 1,233 \\
\hline 11 & 124 & 3,39 & 1,267 & 110 & 2,94 & 1,479 & 129 & 3,00 & $1,29=$ \\
\hline
\end{tabular}

Elde edilen verilere göre katılımcıların Artvin ile ilgili genel olarak olumlu tutuma sahip olduklarını gösteren ifadeler şunlardır; Artvin'in eşsiz bir doğaya sahip olduğu, güvenilir bir şehir olduğu, isminin mutluluğa neden olduğu, şehrin sahip olduğu benzersiz mimari yapısı, kokusu, iklimi ve doğası, tarihi, kültürü, tarımsal ve hayvansal ürünleri vb. gibi özelliklerin hoşlanıldığı, sahip olduğu bu özellikler ile akla gelebildiği, olumsuzluklara karşı şehirlerini desteklemeye devam edecekleri, şehri ziyareti tavsiye edebilecekleri, şehrin kendilerinde güzel hatıralar barındırdığını, şehirde kendilerini özgür hissettikleri ve 
Türkiye'deki diğer şehirlere göre daha özgün bir tarza sahip olduğu gibi ifadelere yüksek katılım olduğu görülmektedir. Buna karşılık şehrin yüksek tanınırlık düzeyine sahip olmaması, hizmet kalitesi, sanayi ürün kalitesi ve turistik ürün kalitesi gibi ifadelere ise düşük bir katılım gözükmektedir.

Bayburt ile ilgili yukarıdaki istatistiki veriler, dikkate alındığında şu sonuçlara ulaşıımaktadır; Katılımcılar şehrin güvenilir olduğu, şehrin güzel hatıralar barındırdığını, şehri hayal etmekte zorlanmadıklarını, sahip olduğu özellikler ile hemen akla geldiğini, gelecekte ne kadar olumsuzlukla karşılaşırlarsa karşılaşsınlar bu şehri sevmeye ve desteklemeye devam edecekleri ve imkân olması halinde şehirden hemen taşınmak istedikleri gibi ifadelere yoğun katılım göstermişlerdir. Bunun yanı sıra şehre yönelik gelişen tanınırlık ve çekicilik yetersizliği, şehrin turistik ve sanayi ürün eksikliği, lider bir şehir olmadığı, tanınmış kişiler tarafından beğenilen ve tavsiye edilen bir şehir olmadığı, şehirde yaşamanın bir prestij oluşturmadığı gibi ifadelere katıım düzeyleri, şehir sakinlerinin sahip şehirlerine yönelik olumsuz tutumlara örnek olarak gösterilebilir.

Tablo 4.'te yer alan bir diğer şehir olan Gümüşhane'nin güvenilir bir şehir olduğu, eşsiz doğal ve tarihi güzelliklere sahip olduğu, şehre dair güzel hatıralar biriktirdikleri, gelecekte ne kadar olumsuzlukla karşılaşıllarsa karşılaşsınlar Gümüşhane'yi sevmeye ve desteklemeye devam edecekleri gibi ifadelere genel olarak olumlu tutum gösterildiği tespit edilmektedir. Şehrin sahip olduğu hizmet kalitesinin, sanayi ürünlerinin yüksek kalitede olmaması, şehrin yüksek bir tanınırlık düzeyine sahip olmaması, şehrin diğer şehirlere göre daha az ilgi çekici olması, bir turist olmaları halinde ilk tercihlerinin Gümüşhane olmayacağı gibi ifadeler katılımcıların şehre yönelik olumsuz tutumlarına örnek olarak gösterilebilir.

\section{Giresun ve Rize'ye Yönelik Tutumlar}

Nüfus oranları bakımından birbirine yakın olan Giresun ve Rize'ye yönelik gerçekleştirilen araştırmayla katılımcıların kendi şehirlerine yönelik tutumları ölçülmeye çalışılmaktadır. Tanımlayı૮ı istatistik analizi sonuçlarına göre katılımcıların verdikleri cevapların ortalamaları üzerinden şehre yönelik tutumlar belirlenecektir.

Giresun'a yönelik gerçekleştirilen araştırmadan elde edilen verilere göre ölçeğin hem örneklem yeterlilik testinin geçerliliği (KMO= ,897) hem de güvenilirliği (Cronbach's Alpha ,953) sağladığı ve önermeler ile ana külte arasında anlamlı bir farklılık olduğu $\left(X^{2}=4689,251, S . D=, 1128, p=, 000\right)$ gözlemlenmektedir. 
Rize'ye yönelik elde edilen verilere göre ise ölçeğin hem örneklem yeterlilik testinin geçerli olduğu (KMO= ,889) hem de güvenilir olduğu (Cronbach's Alpha ,961) ve önermeler ile ana külte arasında anlamlı bir farklılık olduğu $\left(X^{2}=4869,919, S . D=, 1128, p=, 000\right)$ gözlemlenmektedir.

Tablo 5 Giresun ve Rize'ye Yönelik Tutumların Ortalamaları

\begin{tabular}{|c|c|c|c|c|c|c|}
\hline & \multicolumn{3}{|c|}{ Giresun } & \multicolumn{3}{|c|}{ Rize } \\
\hline & $\mathrm{N}$ & ORT. & S.S & $\mathrm{N}$ & ORT. & S.S \\
\hline F8 & 167 & 3,72 & ,992 & 175 & 3,68 & 1,150 \\
\hline Ö6 & 168 & 2,82 & 1,235 & 175 & 3,38 & 1,202 \\
\hline 0̈8 & 167 & 3,20 & 1,101 & 175 & 3,54 & 1,118 \\
\hline F6 & 168 & 4,07 & 970 & 174 & 4,06 & 980 \\
\hline F3 & 167 & 4,01 & 997 & 173 & 3,83 & 1,131 \\
\hline FADEÖ1 & 168 & 3,96 & 972 & 172 & 3,89 & 2,479 \\
\hline $\mathrm{F} 2$ & 168 & 3,78 & 1,041 & 175 & 3,45 & 1,197 \\
\hline F1 & 168 & 4,07 & 1,006 & 174 & 3,67 & 1,227 \\
\hline F5 & 167 & 3,52 & 1,186 & 167 & 3,21 & 1,191 \\
\hline F4 & 168 & 4,02 & ,976 & 174 & 3,84 & 1,095 \\
\hline F7 & 168 & 3,58 & 1,023 & 173 & 3,71 & 1,100 \\
\hline F9 & 168 & 3,50 & 1,137 & 171 & 3,34 & 1,159 \\
\hline $\mathrm{K} 2$ & 167 & 2,93 & 1,193 & 174 & 2,67 & 1,241 \\
\hline K1 & 167 & 2,72 & 1,149 & 175 & 2,41 & 1,200 \\
\hline K3 & 167 & 3,05 & 1,204 & 172 & 3,23 & 1,145 \\
\hline FADEÖ2 & 168 & 3,64 & 1,046 & 174 & 3,72 & 1,166 \\
\hline Ç3 & 168 & 4,34 & ,832 & 175 & 4,30 & 991 \\
\hline Ç1 & 168 & 3,90 & 1,065 & 174 & 3,43 & 1,209 \\
\hline Ç2 & 168 & 3,78 & 963 & 171 & 3,62 & 1,138 \\
\hline Ç4 & 167 & 2,98 & 1,190 & 174 & 3,37 & 1,256 \\
\hline Ö10 & 165 & 3,06 & 1,092 & 171 & 3,30 & 1,168 \\
\hline A15 & 168 & 3,98 & ,997 & 173 & 3,91 & 1,195 \\
\hline Ö1 & 167 & 2,82 & 1,204 & 173 & 3,34 & 1,236 \\
\hline A8 & 168 & 3,93 & ,994 & 171 & 3,81 & 1,124 \\
\hline A7 & 168 & 3,92 & 1,086 & 172 & 3,60 & 1,269 \\
\hline A5 & 168 & 3,84 & 1,005 & 175 & 3,47 & 1,258 \\
\hline A3 & 168 & 3,70 & 1,098 & 173 & 3,40 & 1,242 \\
\hline FADEÖ3 & 168 & 2,27 & 1,275 & 171 & 2,38 & 1,381 \\
\hline A6 & 167 & 3,60 & 1,012 & 173 & 3,40 & 1,176 \\
\hline $\mathrm{A} 1$ & 166 & 3,68 & 947 & 172 & 3,62 & 1,104 \\
\hline$A 2$ & 167 & 3,69 & 1,010 & 174 & 3,47 & 1,171 \\
\hline A12 & 167 & 3,56 & 973 & 172 & 3,74 & 1,269 \\
\hline A10 & 168 & 3,98 & 951 & 172 & 3,85 & 1,112 \\
\hline A4 & 168 & 3,81 & 1,072 & 173 & 3,55 & 1,248 \\
\hline A17 & 168 & 3,92 & 960 & 174 & 3,84 & 1,248 \\
\hline A9 & 167 & 4,09 & ,962 & 175 & 3,83 & 1,229 \\
\hline A16 & 167 & 3,83 & ,864 & 175 & 3,81 & 1,162 \\
\hline
\end{tabular}




\begin{tabular}{llll|lll} 
A14 & 167 & 3,77 &, 963 & 174 & 3,56 & 1,180 \\
K4 & 167 & 3,41 & 1,076 & 175 & 2,95 & 1,236 \\
FADEÖ4 & 167 & 4,10 &, 903 & 175 & 4,02 & 1,102 \\
Ö9 & 167 & 3,43 &, 997 & 174 & 3,32 & 1,158 \\
Ö7 & 167 & 3,13 & 1,050 & 175 & 3,05 & 1,193 \\
Ö1 & 167 & 2,66 & 1,145 & 172 & 3,21 & 1,377 \\
Ö2 & 166 & 2,92 & 1,267 & 175 & 3,67 & 1,288 \\
Ö4 & 167 & 3,15 & 1,096 & 174 & 3,26 & 1,302 \\
Ö3 & 166 & 2,99 & 1,101 & 172 & 3,57 & 1,210 \\
A13 & 167 & 3,59 & 1,048 & 175 & 3,53 & 1,203 \\
A11 & 167 & 3,82 & 1,066 & 174 & 3,65 & 1,230 \\
\hline
\end{tabular}

Elde edilen verilere göre Giresun üzerine gerçekleştirilen araştırmaya katılan denekler, şehrin güvenilir olduğu, şehrin ismini ne zaman duysalar mutlu oldukları, sahip olduğu özellikle eşsiz doğal ve tarihi ile şehrin sahip olduğu tüm özelliklerin hemen akla geldiği, şehrin logosunu nerde görseler tanıyabilecekleri gibi ifadelere yoğun bir katılım göstermektedirler. Buna rağmen katılımcılar, Giresun'un Doğu Karadeniz Bölgesi'nde önde gelen/lider bir şehir olmadığını düşünmekte, şehrin bir marka şehir olmadığı, şehrin sunduğu hizmetlerin ve sanayi ürünlerinin yüksek kalitede olmadığı görüşündedirler.

Tablo 5'te yer alan veriler incelendiğinde katılımcılar Rize'nin eşsiz doğal güzelliklere sahip olduğunu, sahip olduğu tüm özellikleri ile hemen akla geldiği, şehrin güvenilir olduğu, gelecekte ne kadar olumsuzluklarla karşılaşırlarsa karşılaşsınlar bu şehri sevmeye ve desteklemeye devam edecekleri, şehrin sahip olduğu özgün sembolün hatırlanma düzeyinin yüksek olduğu, şehrin mimari yapısı, kokusu, iklimi, doğası vb. her şeyiyle hoşlarına gittiği, şehirde yaşamanın kendilerine mutluluk verdiğini, imkanları el verse bile bu şehirden taşınmak istemeyecekleri gibi ifadelere yoğun katılım gösterirken, hizmet kalitesinin ve sanayi ürünlerinin düşük kalitede olduğu ve şehrin sürdürülebilir bir gelişmeden uzak olduğunu düşünmektedir.

\section{Ordu ve Trabzon'a Yönelik Tutumlar}

Yine nüfus oranlarına göre birbirlerine yakın olan Ordu ve Trabzon şehirlerine yönelik analizler Tablo 6'da birlikte ele alınarak, araştırma kapsamında katılımcıların kendi şehirlerine yönelik tutumları ölçülmeye çalışılmaktadır. Tanımlayıcı istatistik analizi sonuçlarına göre katılımcıların verdikleri cevapların ortalamaları üzerinden şehre yönelik tutumlar ortaya konmaya çalışılmaktadır. 
Ordu özelinde gerçekleştirilen araştırmada elde edilen sonuçlara göre ölçeğin hem geçerliliği $(K M O=, 895)$ hem de güvenilirliği (Cronbach's Alpha ,944) sağladığı ve önermeler ile ana külte arasında anlamlı bir farklılık olduğu $\left(X^{2}=6317,218, S . D=, 1128, p=, 000\right)$ görülmektedir.

Trabzon özelinde gerçekleştirilen araştırma sonuçlarına göre ise, ölçek örneklem yeterlilik testini sağlamaktadır (KMO= ,925) ve mükemmel derecede güvenilirdir (Cronbach's Alpha ,958). Bartlett's testine göre ise, her bir önerme ile ana kütle arasında anlamlı bir farklılık olduğu da $\left(X^{2}=7034,073\right.$, $\mathrm{S} . \mathrm{D}=, 1128, \mathrm{p}=, 000)$ ortaya çıkmaktadır.

Tablo 6. Ordu ve Trabzon'a Yönelik Tutumların Ortalamaları

\begin{tabular}{|c|c|c|c|c|c|c|}
\hline & \multicolumn{3}{|c|}{ Ordu } & \multicolumn{3}{|c|}{ Trabzon } \\
\hline & $\mathrm{N}$ & ORT. & S.S & $\mathrm{N}$ & ORT. & S.S \\
\hline F8 & 240 & 3,60 & 1,135 & 271 & 3,77 & 1,081 \\
\hline 0̈6 & 239 & 3,01 & 1,168 & 270 & 3,69 & 1,002 \\
\hline 0̈8 & 238 & 3,29 & 1,109 & 271 & 3,61 & 1,030 \\
\hline F6 & 240 & 3,83 & 1,044 & 269 & 4,25 & ,833 \\
\hline F3 & 239 & 3,74 & 1,057 & 268 & 3,90 & 1,073 \\
\hline FADEÖ1 & 238 & 3,59 & 1,030 & 272 & 3,87 & 1,054 \\
\hline $\mathrm{F} 2$ & 239 & 3,64 & 1,121 & 272 & 3,71 & 1,172 \\
\hline F1 & 240 & 3,83 & 1,077 & 272 & 4,00 & 1,092 \\
\hline F5 & 239 & 3,53 & 1,107 & 272 & 3,84 & 1,143 \\
\hline F4 & 240 & 3,89 & ,994 & 269 & 4,19 & ,932 \\
\hline F7 & 239 & 3,62 & 1,054 & 272 & 4,04 & 1,017 \\
\hline F9 & 240 & 3,65 & 1,076 & 271 & 3,79 & 1,017 \\
\hline $\mathrm{K} 2$ & 239 & 3,13 & 1,118 & 271 & 2,80 & 1,088 \\
\hline K1 & 238 & 3,03 & 1,167 & 272 & 2,57 & 1,003 \\
\hline K3 & 239 & 3,21 & 1,115 & 270 & 3,43 & 1,039 \\
\hline FADEÖ2 & 239 & 3,52 & 1,111 & 273 & 3,83 & 1,011 \\
\hline Ç3 & 239 & 4,25 & ,885 & 272 & 4,43 & ,760 \\
\hline Ç1 & 239 & 3,79 & 1,064 & 271 & 4,17 & ,845 \\
\hline Ç2 & 238 & 3,74 & 1,003 & 267 & 3,98 & ,994 \\
\hline Ç4 & 239 & 3,15 & 1,200 & 272 & 3,20 & 1,245 \\
\hline 0̈10 & 239 & 3,24 & 1,232 & 270 & 3,06 & 1,238 \\
\hline A15 & 239 & 3,67 & 1,054 & 273 & 3,93 & 1,023 \\
\hline Ö5 & 239 & 3,19 & 1,120 & 272 & 3,57 & 1,105 \\
\hline A8 & 239 & 3,91 & ,981 & 271 & 3,80 & 1,077 \\
\hline A7 & 238 & 3,77 & 1,141 & 271 & 3,69 & 1,262 \\
\hline A5 & 239 & 3,69 & 1,080 & 273 & 3,55 & 1,191 \\
\hline A3 & 239 & 3,49 & 1,181 & 272 & 3,54 & 1,196 \\
\hline FADEÖ3 & 239 & 2,34 & 1,283 & 268 & 2,43 & 1,292 \\
\hline A6 & 237 & 3,51 & 1,096 & 267 & 3,58 & 1,005 \\
\hline A1 & 239 & 3,62 & 1,013 & 271 & 3,55 & 1,114 \\
\hline$A 2$ & 238 & 3,52 & 1,058 & 272 & 3,69 & 1,127 \\
\hline
\end{tabular}




\begin{tabular}{llll|lll} 
A2 & 239 & 3,51 & 1,084 & 272 & 3,83 & 1,114 \\
A10 & 239 & 3,87 &, 984 & 271 & 4,02 &, 979 \\
A4 & 239 & 3,64 & 1,083 & 273 & 3,55 & 1,187 \\
A17 & 239 & 3,92 &, 976 & 273 & 3,90 & 1,006 \\
A9 & 239 & 3,78 & 1,074 & 269 & 4,04 &, 978 \\
A16 & 238 & 3,91 & 1,015 & 267 & 4,00 &, 934 \\
A14 & 238 & 3,72 &, 993 & 266 & 3,73 & 1,048 \\
K4 & 238 & 3,42 & 1,002 & 267 & 3,32 & 1,144 \\
FADEÖ4 & 238 & 3,80 &, 924 & 269 & 4,14 &, 966 \\
Ö9 & 238 & 3,53 &, 971 & 269 & 3,51 & 1,021 \\
Ö7 & 238 & 3,24 & 1,067 & 267 & 3,28 & 1,007 \\
Ö1 & 238 & 2,85 & 1,177 & 267 & 3,39 & 1,130 \\
Ö2 & 238 & 3,42 & 1,118 & 268 & 4,15 &, 919 \\
Ö4 & 238 & 3,22 & 1,089 & 267 & 3,42 & 1,102 \\
Ö3 & 238 & 3,22 & 1,092 & 268 & 3,47 & 1,002 \\
A13 & 239 & 3,65 & 1,038 & 269 & 3,64 & 1,116 \\
A11 & 239 & 3,71 & 1,095 & 268 & 3,69 & 1,245 \\
\hline
\end{tabular}

Elde edilen veriler incelendiğinde katılımcıların Ordu şehrine yönelik geliştirilen "Bu şehir eşsiz doğal güzelliklere sahiptir" önermesine en yüksek katılım oranı göstererek, bu şehirde yaşamaktan mutlu olduklarını, şehrin mimari yapısı, kokusu, iklimi, doğası vb. her şeyiyle hoşlarına gittiğini ve bu özellikleri için tavsiye ettikleri, şehrin kendilerinde güzel hatıralar barındırdığı, şehrin sahip olduğu özelliklerinin hemen akla gelerek, şehri hayal etmekte zorlanmayacakları gibi ifadelere de yüksek bir katılım ile oranı ile katıldıkları görülmektedir. Buna karşın, iki ifadeye deneklerin olumsuz katılım gösterdikleri görülmektedir. Bunlardan biri Ordu'nun Türkiye'de önde gelen/lider bir şehir olduğu görüşüdür. Diğer ifade ise imkanları olsa, bu şehirden hemen taşınabilecekleridir.

Trabzon'una yönelik genel tutumlar incelendiğinde katılımcılar, sahip olduğu eşsiz doğal, tarihi gibi özellikleri ile Trabzon şehrinin hemen akıllarına geldiğini, yine şehrin sahip olduğu birçok değer, gösterge vb. dolayı yüksek bir hatırlanma düzeyine sahip olduğu ve şehri hayal etmekte zorlanmayacakları, Doğu Karadeniz Bölgesi'nde önde/lider bir şehir olduğu, şehrin güvenilir bir şehir olduğu, ismini ne zaman duysalar mutlu oldukları ve şehrin kendilerinde güzel hatıralar barındırdığı gibi ifadelere yüksek oranda katılım göstermektedirler. Bu olumlu tutumların yanında katılımcılar Trabzon ile ilgili iki önermeye olumsuz tutum sergilemektedirler. Katılımcılara göre Trabzon şehri sahip olduğu hizmet kalitesi ve sanayi ürünleri bakımından yüksek kalitede bir şehir değildir. 


\section{Doğu Karadeniz Şehirlerine Yönelik Genel Tutum Bileşenlerinin Demografik}

\section{Özelliklere Göre Farklılaşma Durumu}

Doğu Karadeniz şehirlerine yönelik genel tutumları oluşturan bileşenlerin demografik özelliklere göre farklılık gösterip göstermediğini test etmek amacıyla One Way Anova ve Independent Sample Ttestinden yararlanılmıştır. Gerçekleştirilen One Way Anova testine göre araştırmaya katılan deneklerin yaş değişkeni açısından aidiyet ( $d f=1142 ; f=8,941 ; p=, 000)$, özdeğer ( $d f=1141 ; f=3,201 ; p=, 007)$, farkındalık ( $d f=1131 ; f=2,617 ; p=, 023$ ) ve çekicilik ( $d f=1168 ; f=5,670 ; p=, 000)$ faktörlerinde anlamlı farklıı̆̆ın ortaya çıktığı, buna karşın kalite faktöründe ise (df=1163; $f=, 603 ; p=, 698)$ anlamlı bir farklılı̆ıın olmadığı görülmektedir. $\mathrm{H}_{4}$ nispeten doğrulanmıştır. Diğer taraftan gelir değişken açısından tutumları oluşturan bileşenler arasında anlamlı bir farklıı̆ın olmadığı $(>, 05)$ ortaya çıkmaktadır. $H_{5}$ doğrulanamamıştır. Eğitim durumu açısından ise tüm faktörlerde anlamlı bir farklılığın olduğu anlaşılmaktadır. Buna göre;

- Aidiyet ( $\mathrm{df}=1145 ; \mathrm{f}=9,840 ; \mathrm{p}=, 000$ ) (Post Hoc Testi sonuçlarına göre ilkokul mezunları ile ön lisans $(p=, 000)$ ve lisans mezunları $(p=, 000)$ arasında, yine ortaokul mezunlarıyla ön lisans $(p=, 001)$ ve lisans mezunları $(p=, 000)$ arasında)),

- Özdeğer ( $d f=1142 ; f=11,975 ; p=, 000$ ) (Post Hoc Testi sonuçlarına göre ön lisans mezunlarıyla ilkokul $(p=, 000)$, ortaokul $(p=, 000)$ ve lise $(p=, 000)$; lisans mezunlarıyla ise yine ilkokul $(p=, 000)$, ortaokul $(p=, 000)$ ve lise $(p=, 005)$ mezunlarıyla)),

- Farkındalık ( $d f=1132 ; f=5,126 ; p=, 000$ ) (Post Hoc Testi sonuçlarına göre ön lisans mezunlarıyla ilkokul $(p=, 006)$, ortaokul $(p=, 014)$ ve lise $(p=, 011)$ mezunları arasında)),

- Kalite $(\mathrm{df}=1165 ; \mathrm{f}=10,711 ; \mathrm{p}=, 000)$ (Post Hoc Testi sonuçlarına göre (ilkokul mezunları ile ön lisans $(p=, 017)$, lisans $(p=, 000)$ ve lisansüstü $(p=, 032)$ arasında, yine ortaokul mezunlarıyla lise $(p=, 028)$, ön lisans $(p=, 000)$, lisans mezunları $(p=, 000)$ ve lisansüstü $(p=, 001)$ ve lise mezunlarıyla ön lisans $(p=, 039)$ ve lisans mezunları $(p=, 000)$ arasında)),

- Çekicilik ( $\mathrm{df}=1169 ; \mathrm{f}=, 7,355 ; \mathrm{p}=, 000$ ) (Post Hoc Testi sonuçlarına göre (ilkokul mezunları ile ön lisans ( $p=, 001)$, lisans ( $p=, 001)$; ortaokul mezunlarıla ön lisans $(p=, 007)$, lisans $(p=, 011)$ ve lise mezunlarıyla ön lisans $(p=, 002)$, lisans $(p=, 005)$ arasında)), anlamlı farklılık bulunmaktadır. $\mathrm{H}_{3}$ doğrulanmıştır. 
Independent Sample T-testi sonuçlarına göre ise cinsiyet değişkeni açısından özdeğer (df=1148; $f=4,443 ; p=, 035)$ ve kalite faktörü $(d f=1171 ; f=5,686 ; p=, 017)$ açısından anlamlı farklılığın olduğu görülmüştür. Diğer faktörler açısından anlamlı bir farklııı̆a $(>, 05)$ rastlanmamıştır. Dolayısıyla $\mathrm{H}_{1}$ nispeten doğrulanmıştır. Medeni durum açısından incelendiğinde ise sadece aidiyet ( $d f=1147 ; f=4,828$; $\mathrm{p}=, 028$ ) ve kalite faktörü ( $d f=1168 ; f=4,903 ; \mathrm{p}=, 027)$ açısından anlamlı bir farklılık ortaya çıkmıştır. $\mathrm{H}_{2}$ nispeten doğrulanmıştır.

\section{SONUÇ}

Markalaşmayı sadece dış hedef kitle odaklı bir çalışma olarak ele almak sığ bir yaklaşımdır. Halbuki markalaşmanın kendisi tam anlamıyla stratejik bir eylemi gerektirir. Dolayısıyla markalaşmayı sadece dış hedef kitle ile kısıtlamak yerine iç hedef kitleyi de sürece dahil etmek gerekmektedir. Ancak markalaşma üzerine gerçekleştirilen araştırmaların birçoğu bu yaklaşımdan mahrumdur.

iç hedef kitle üzerine odaklanan bu çalışmada Doğu Karadeniz şehirlerinin markalaşmasına yönelik tutumlar üzerine odaklanılmaktadır. Araştırmaya dahil edilen 7 şehirde ikamet eden katıımcılara kendi şehirleri ile ilgili tutumları sorulmuştur. Elde edilen sonuçlara göre iç hedef kitlenin tutumlarını beş faktör etkilemektedir. Bunları aidiyet, özdeğer, farkındalık, kalite ve çekicilik faktörleri oluşturmaktadır.

Şehir Aidiyeti: Şehir sakinlerinin kendilerini o şehre ait hissetme durumlarını vurgulamaktadır. Şehir ile sakinler arasındaki bağın gücü markalaşma sürecinin belirleyicisi konumundadır. Kişinin kendini o şehre ait hissetmesi, aynı zamanda o şehrin bir savunucusu ve gönüllü elçisi olmasını sağlamaktadır. Doğu Karadeniz şehirleri bu bağlamda değerlendirildiğinde şehir sakinlerinin şehirlerini kendilerinin ayrılmaz bir parçası olarak gördükleri anlaşılmaktadır. Katılımcıların şehirlerini gelecekte ne kadar olumsuzlukla karşılaşırlarsa karşılaşsınlar sevmeye ve desteklemeye devam edecekleri, sosyal çevrelerine ziyaret etmeleri için tavsiye edebilecekleri ve mimari yapısı, kokusu, iklimi, doğası vb. her şeyiyle hoşlarına giden bir şehir olarak gördükleri anlaşılmaktadır.

Şehrin Özdeğeri: Şehrin sahip olduğu özdeğeri, niteliklerinin ne kadar yüksek olduğu ile ilgilidir. Şehrin üstün kalite niteliklerinden prestij göstergelerine, tanınırlık seviyesinden önde gelen bir şehir olmasına kadar bir dizi niteliğin seviyesi ne kadar yüksek olursa şehrin markalaşma ihtimali o oranda yükselmektedir. Doğu Karadeniz Bölgesi'nde yer alan şehirlerin, bu çerçevede Türkiye'de önde gelen bir şehir olma ve turistik bir yer olarak istikrarlı bir şekilde tercih edilme konusunda olumsuz bir yaklaşıma 
sahip olunmasına rağmen birçok konuda üstün özdeğer niteliklerine sahip olduğu görülmektedir. Bunlar iyi değer sunan, Türkiye'de ilgi çekici, kendi bölgesinde lider ve tanınmış kişiler tarafından beğenilentavsiye edilen bir şehir olma özdeğerleri olarak vurgulanmaktadır.

Şehrin Farkındalığı: Markanın en önemli belirleyicilerinden biri olan farklılaşma ve buna bağı olarak bu farklılaşmanın yansıtılması yani farkındalı̆ıın oluşturulması, şehirler için de olmazsa olmazlardandır. Şehrin akılda kalıı özgün değerlere sahip olması ve bu değerlerin yüksek dikkat çekme ve hatırlanma düzeyine ulaşması rakip şehirler arasından ayrışmayı sağlamaktadır.

Şehrin Kalite Niteliği: Markanın belirli bir kalite standardına sahip olması gerektiği muhakkaktır. Marka olmak isteyen bir şehrinde sahip olduğu ürün ve hizmetlerinde üst seviyede kalite niteliğine sahip olması gerekir. Gerçekleştirilen bu araştırmaya göre, katılımcılar kendi şehirlerinin sürekli olarak özelliklerini geliştirdiği/iyileştirdiğini düşünmektedirler ve yine şehirlerinin sahip olduğu turistik ürünlerinin nispeten yüksek kalitede olduğunu iddia etmektedirler. Buna karşın onlara göre şehirlerinin sanayi ürünleri ve hizmet kalitesi düşüktür. Bu durum Doğu Karadeniz Bölgesi'ndeki şehirlerin markalaşma yolundaki en büyük zaafları olarak görülebilir.

Şehrin Çekiciliği: Çekicilik unsurları markaya olan talebin artmasını sağlar. Bir ürün ya da hizmet ne kadar kaliteli ve üstün niteliklere sahip olursa olsun, belli bir oranda çekicilik unsuruna sahip değilse, o ürün ya da hizmetin yeterince talep görmesi veya marka haline gelmesi mümkün değildir. Özellikle turistleri çekmek isteyen bir şehrin de marka değerine kavuşabilmesi veya yeterince talep oluşturabilmesi için çekicilik unsurlarına sahip olması gerekmektedir. Doğu Karadeniz şehirleri ele alındığında katıımcılara göre bu bölgedeki şehirler eşsiz tarihi, kültürel ve doğal güzelliklere sahiptir. Bu durum Doğu Karadeniz şehirlerinin yüksek çekicilik unsurlarına sahip olduğunu ortaya koymakla birlikte katılımcıların turist olmaları halinde ilk tercihlerinin kendi şehirleri olmayacağını dile getirdikleri görülmektedir. Bu durum, bölge şehirlerinin kalite niteliklerinin düşük olması ve insanların kendi şehirlerinin güzelliklerini kanıksamasıyla açıklanabilir. Bu konuda daha sağlıklı bir sonuç elde etmek için dış hedef kitleye yönelik ayrı bir araştırmanın yapılması yerinde olacaktır.

Sonuç olarak Doğu Karadeniz Bölgesi'nde yer alan şehirlerin marka haline gelebilmesi için öncelikle şehir sakinleri özelinde aidiyet duygusunu geliştirmeleri, özdeğer niteliklerine sahip olmaları, farkındalık oluşturacak derecede farkılışmaları, üst düzey kalite niteliklerine ve çekicilik unsurlarına 
sahip olmaları gerekmektedir. Ayrıca Miyopluk, Hatalı Odaklanma, Minimize Etme, Hatalı Konumlandırma ve Hatalı Pazarlama gibi şehirlerin yapmaması gereken hatalara dikkat edilmesi Doğu Karadeniz şehirlerinin markalaşma süreçlerini olumlu yönde etkileyecektir. Marka şehir oluşum sürecinin başarısı için ise; Marka şehir platformunun kurulması sağlanmalı, bu çerçevede şehirde yaşayanlarda marka şehir bilinci inşa edilmeli, yerel gurur öğeleri yaratılmalı, başarıya inanç algısı inşa edilmeli, marka şehir bilinci içselleştirilmeli ve marka şehir iletişimi yönetimine önem verilmelidir.

\section{EXTENDED ABSTRACT}

\section{Introduction}

Cities, besides being a settlement, are also centers of social, cultural and economic interaction. One of the most important tasks of cities is to increase the peace and well-being of their citizens. In order for cities to fulfill these tasks, they must produce intangible values as well as tangible values. Brand is at the top of intangible values. The fact that cities have intangible values through branding means that a product reaches higher income than it can reach. It is seen that cities that want to reach high income have attached importance to branding efforts in recent years. Branding studies are mostly aimed at external target audience. However, any product, service or value that is not branded in the internal target audience will not be truly branded. The internal target group, one of the most important representatives of the brand, is also a carrier and builder of the brand.

\section{Subject of the research}

The high welfare of Western societies and their efforts to turn almost everything into a capitalist value, it enabled cities to be included in this transformation. Cities that develop strategies for their own markets, target audiences, consumers and customers have become a successful brand in this process. They have developed their fields of activity in order to have and protect a brand. However, it is a fact that it is not possible for all places and regions to develop and enrich at the same time. In an environment where resources are scarce, it is quite natural to have winners and losers (ilgüner \& Asplund, 2011, p.12). However, those who make the right strategic brand investment and thus become a brand have a high success rate from this struggle. 
On the other hand, Turkey's eastern Black Sea located examined cities in which they reached is a real potential for a major tourist destination in recent years. The continuity of this intense demand for the Eastern Black Sea region, which is especially preferred by Arab tourists, is only possible if the region and the cities of the region become a brand. However, in order to gain value in the eyes of the external target audience, it must be perceived as a brand by the internal target audience. This research, in which the attitude of the target audience towards their own city is tried to be explored, will be a guide to brand city strategies for eastern black sea cities.

\section{The Purpose and The Importance of the Research}

Studies on branding mostly focus on measuring attitudes towards external stakeholders. But this study focuses on the internal target audience, in other words, individuals residing in that city, aims to measure individuals' brand attitudes towards their cities. Therefore, the study was carried out on city residents residing in 7 cities (Artvin, Bayburt, Giresun, Gümüşhane, Ordu, Rize, Trabzon) located in the Eastern Black Sea Region. This study, which aims to measure the residents' brand city attitudes towards their own cities, is important because it is one of the first in its field also it will be a guide in the field.

\section{The Scope and The Method of the Research}

In this study conducted on seven cities in the Eastern Black Sea Region, city residents living in each city were asked about their brand attitudes about their cities and the answers obtained were analyzed. While determining the scope and limitations of the study, the sample sizes in this study conducted in the city centers of the Eastern Black Sea Region were determined according to the population size of the cities. Accordingly, a total of 1.315 questionnaires were applied on city residents, 270 in Trabzon and Ordu, 200 in Rize and Giresun, 125 in Gümüşhane, Artvin and Bayburt.

In this study, in which data were collected with a questionnaire (survey), one of the quantitative research methods, the results analyzed with the help of the statistical package program were basically examined in two different dimensions. Using frequency, reliability, and factor analysis, this study was applied on 1315 people and 1221 questionnaires were included in the study. While the first dimension includes attitudes towards the cities of the region with the data collected from all cities, in the second dimension, each city is analyzed separately. 


\section{The Findings}

The research was completed by analyzing the data obtained from a total of 1221 participants. In this study, it is seen that general brand attitudes towards the cities of the region can be conceptualized within the framework of five factors. These; belonging, self-worth, awareness, quality and attractiveness. These 5 factors were subjected to a comparative analysis among the cities identified.

When the research data were analyzed, many different findings were identified. Some key findings are as follows:

- Cities in the Eastern Black Sea Region are safe cities,

- Agricultural and animal products of these cities are of high quality,

- The remembering level of the symbols of these cities is high,

- City residents generally have a positive attitude towards their city.

\section{Conlusion}

It is a shallow approach to consider branding as a work focused solely on external target audience. However, branding itself requires a strictly strategic action. Therefore, instead of restricting branding with only the external target audience, it is necessary to include the internal target audience in the process. However, most of the research on branding lacks this approach.

As a result, in order for cities in the Eastern Black Sea Region to become a brand, they must first develop a sense of belonging, have self-worth qualities, differentiate to a level to create awareness, and have high-quality qualities and attractiveness. In addition, paying attention to the mistakes that cities should not make such as Myopia, Incorrect Focus, Minimization, Incorrect Positioning and Incorrect Marketing will positively affect the branding processes of Eastern Black Sea cities. For the success of the brand city formation process; Brand city platform should be established, brand city awareness should be built, local pride elements should be created, a sense of belief in success should be built, brand city awareness should be internalized and brand city communication management should be given importance. 


\section{KAYNAKÇA}

Aaker, D. A. (2009). Marka değeri yönetimi. (E. Orfanlı, Çev.) İstanbul: MediaCat yayınları.

Akkaya, F., \& Sezgin, M. (2015). Doğu Karadeniz Bölgesinde Arap Turizmi-mevcut durum ve gelişme stratejisi raporu. Doğu Karadeniz Kalkınma Ajansı (DOKA). Trabzon: DOKA. 012021 tarihinde https://www.doka.org.tr/dosyalar/editor/files/dogu-karadeniz-bolgesinde-arap-turizmimevcut-durum-analizi-ve-gelisme-stratejisi.pdf adresinden alındı

Aslan, E. Ş. (2018, Ekim). Şehirlerin markalaşmasında ortak aklın yaratılması: Bir marka Kent platformu oluşturma arayışı. Çağdaş Yerel Yönetimler Dergisi, 27(4), 29-61.

Broadbent, S. (2003). Hesap verebilen reklam. İstanbul: Reklamcılık vakfı.

Buckingham, I. P. (2011). Brand Champions. New York: Palgrave Macmillan.

Doyle, P. (2001). Başarıı markalar oluşturma. (L. Butterfield, Dü., \& M. Ayın, Çev.) İstanbul: Reklamcılık vakfı.

Elden, M. (2009). Reklam ve Reklamclık. İstanbul: Say yayınları.

Forrest, C. (2001). Nicel veriler ve reklam stretjisi geliştirme. (L. Butterfield, Dü., A. Muharrem , \& vd., Çev.) İstanbul: Reklamcılık vakfı yayınları.

Franzen, G. (2002). Reklamın marka değerine etkisi. İstanbul: MediaCat yayınları.

Herstein , R., Berger, R., \& Jaffe, E. D. (2013, Winter 2013-2014). Five typical city branding mistakes: Why cities tend to fail in implementation of rebranding strategies. Journal of Brnad Strategy, 2(4), 392-402.

Işık, M., \& Erdem, A. (2015). Nasıl marka şehir olunur? Konya: Eğitim yayınevi.

Illgüner, M., \& Asplund, C. (2011). Marka Şehir. İstanbul: Markating yayınları.

Kavaratzis, M. (2004). From city marketing to city branding: Towards a theoretical framework for developing city brands. Place Branding, 58-73.

Keleş, R. (2005). Kent ve Kültür üzerine. Mülkiye Dergisi, 29(246), 9-18.

Keller, K. L. (2008). Strategic brand management: Building, measuring and managing brand equity (3 b.). New Jersey: Pearson Education.

Klein, N. (2002). No logo. (U. Nalan, Çev.) Ankara: Bilgi yayınları.

Moon, M., \& Millison, D. (2003). Ateşten markalar internet çağında marka sadakati yaratmanın yolları. İstanbul: MediaCat yayınları.

Roll, M. (2011). Asya'da marka stratejisi: Asya nasıl güçlü markalar yaratır? İstanbul: Brandage yayınları.

Urry, J. (2009). Turist Bakışı. Ankara: Bilgesu yayıncılık.

Ustakara, F. (2015). Kent markalama:Stratejik iletişim bağlamında marka şehir projesi. Konya: Literatürk Academia.

Vazquez, R., Rio, A. B., \& Iglesias, V. (2002). Consumer-based Brand Equity: Development and Validation of a Measurement Instrument. Journal of Marketing Management, 27-48. 
www.dkbb.gov.tr. (2021, 01 09). Üye Bilgileri. 012021 tarihinde Doğu Karadeniz Belediyeler birliği: http://www.dkbb.gov.tr/?page_id=491 adresinden alındı

www.hurriyet.com. (2018, 08 30). Karadeniz'e Arap turist akını-DHA. 012021 tarihinde Hurriyet.com: https://www.hurriyet.com.tr/karadenize-arap-turist-akini-40941209 adresinden alındı 